\title{
Cystic kidneys in a neonate: do not forget to examine pupils
}

\author{
Piyush Mittal, Amrit Kaur, Jogender Kumar 다 , Praveen Kumar
}

Pediatrics, Post Graduate Institute of Medical Education and Research, Chandigarh, India

\section{Correspondence to} Dr Jogender Kumar: jogendrayadv@gmail.com

Accepted 17 June 2020

\section{DESCRIPTION}

A male infant was born out of third-degree consanguineous marriage at 36 -week gestation with a birth weight of $2340 \mathrm{~g}$. The antenatal ultrasound at 23 weeks of gestation showed enlarged, hyperechoic kidneys with normal liquor. On physical examination, he had generalised oedema, prominent eyes, axial hypotonia and fixed contractures at bilateral knee joints (figure 1). The prominent eyes prompted us to do an ophthalmological examination. We noticed that his pupils were small, constricted and non-responsive to light. The pupils remained miotic even after instillation of tropicamide and atropine (figure 2). Refractory microcoria, along with cystic kidney disease in the neonatal period, raised the possibility of Pierson syndrome and directed further evaluation. The postnatal ultrasound showed enlarged (right kidney $6.3 \mathrm{~cm}$, left kidney $6.8 \mathrm{~cm}$ ), globular hyperechoic kidneys, with poor corticomedullary differentiation. Laboratory evaluation revealed nephrotic range proteinuria (urine protein $3.9 \mathrm{~g} / \mathrm{dL}$, urine dipstick $3+$ ), hypoalbuminemia (albumin $1.9 \mathrm{~g} / \mathrm{dL}$ ) and hyperlipidemia (serum cholesterol $277 \mathrm{mg} / \mathrm{dL}$, serum triglyceride $628 \mathrm{mg}$ / $\mathrm{dL}$ ) consistent with the diagnosis of congenital nephrotic syndrome. It further strengthened our suspicion of Pierson syndrome; therefore, genetic analysis by targeted gene sequencing was done.

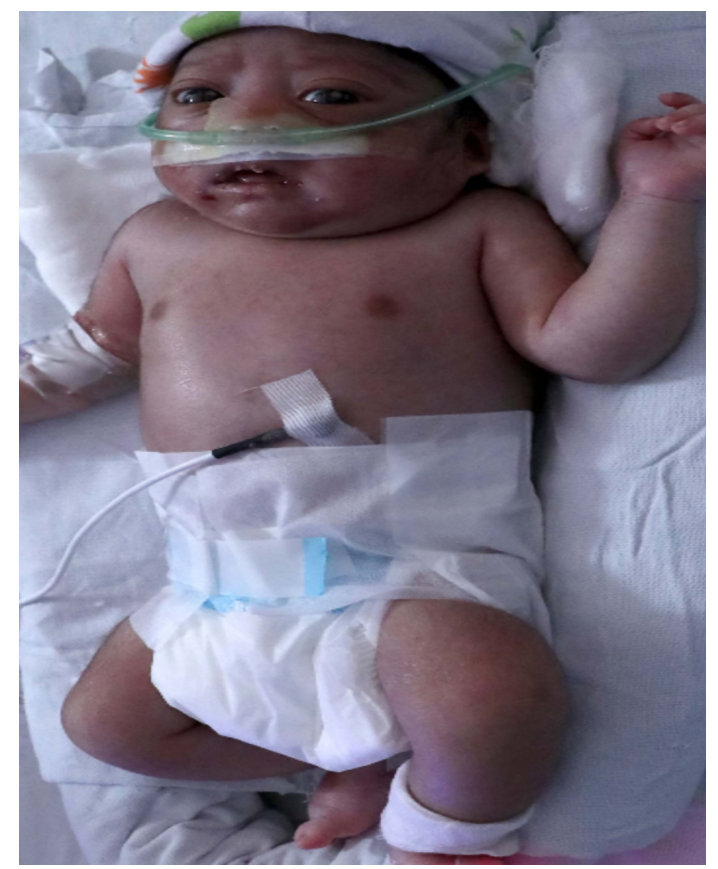

Figure 1 Generalised oedema and contractures at bilateral knee joints.

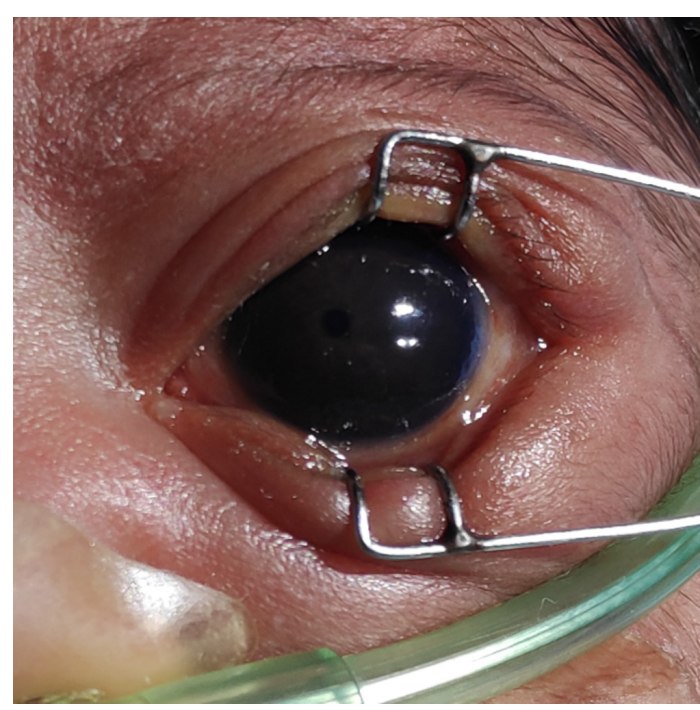

Figure 2 Pupil is miotic and refractory to atropine ointment.

A homozygous non-sense variation in exon 23 of the LAMB2 gene (chr3:g.49161965G >A) that results in a stop codon and premature truncation of the protein at codon 1064 (p.Gln1064Ter) was detected. This is a novel mutation and has not been reported until in 1000 Genomes Project and ExAC database. $^{12}$

He worsened with oliguria and anasarca leading, to pulmonary oedema, and respiratory distress for which continuous positive airway pressure support, albumin infusion and diuretics were given. The anasarca was refractory to diuretics and albumin infusions. Because of poor prognosis, parents decided to discontinue treatment and he died at the age of 17 days.

Pierson syndrome is caused by mutations in $\beta 2$-laminin encoded by the LAMB2 gene and is clinically characterised by congenital nephrotic syndrome and bilateral microcoria. ${ }^{3}$ Presence of characteristic eye findings helps in clinically differentiating this entity from other causes of congenital nephrotic syndrome. ${ }^{4}$ It exhibits good genotype-phenotype correlation. The patients with milder forms of Pierson syndrome have at

\section{Patient's perspective}

It was painful to us when we came to know that our baby is having such a severe medical condition. Despite the best efforts of the doctors, the fate of our child cannot be changed. 
least one missense or non-truncating deletion mutation, while those with more severe phenotype have two truncating mutations. ${ }^{5}$ Our patient had a homozygous non-sense mutation resulting in premature truncation of the protein leading to severe phenotype.

Renal involvement is universal and is associated with ocular and neuromuscular abnormalities. The ocular manifestations are microcoria (the most common and characteristic), megalocornea, glaucoma, microphthalmia, posterior lenticonus, cataract, persistent fetal vasculature and retinal detachment. ${ }^{4}$ Owing to the expression of LAMB2 gene in the neuromuscular system, neurological manifestations, such as muscle hypotonia, contractures and neurodevelopmental abnormalities are also seen. ${ }^{6}$ The

\section{Learning points}

- Pierson syndrome is a rare cause of congenital nephrotic syndrome.

- Early renal impairment in the neonatal age group and characteristic eye findings helps in clinically differentiating. Pierson syndrome from other causes of congenital nephrotic syndrome.

- Mutational analysis of LAMB2 gene is considered diagnostic for this entity. overall prognosis is poor and most of the affected individuals die in infancy only.

Contributors PM and AK managed the case and JK and PK supervised the clinical management. PM and AK drafted the manuscript, JK and PK critically reviewed and revised the manuscript. All authors approved the final version and shall be responsible for all aspects of the work.

Funding The authors have not declared a specific grant for this research from any funding agency in the public, commercial or not-for-profit sectors.

Competing interests None declared.

Patient consent for publication Parental/guardian consent obtained.

Provenance and peer review Not commissioned; externally peer reviewed.

ORCID iD

Jogender Kumar http://orcid.org/0000-0002-0464-9689

\section{REFERENCES}

11000 Genomes Project Consortium, Auton A, Brooks LD, et al. A global reference for human genetic variation. Nature 2015;526:68-74.

2 Lek M, Karczewski KJ, Minikel EV, et al. Analysis of protein-coding genetic variation in 60,706 humans. Nature 2016:536:285-91.

3 Chew C, Lennon R. Basement membrane defects in genetic kidney diseases. Front Pediatr 2018:6:11.

4 Bredrup C, Matejas V, Barrow M, et al. Ophthalmological aspects of Pierson syndrome. Am J Ophthalmol 2008;146:602-11.

5 Matejas V, Hinkes B, Alkandari F, et al. Mutations in the human laminin beta2 (LAMB2) gene and the associated phenotypic spectrum. Hum Mutat 2010;31:992-1002.

6 Wühl E, Kogan J, Zurowska A, et al. Neurodevelopmental deficits in Pierson (microcoriacongenital nephrosis) syndrome. Am J Med Genet A 2007;143:311-9.

Copyright 2020 BMJ Publishing Group. All rights reserved. For permission to reuse any of this content visit https://www.bmj.com/company/products-services/rights-and-licensing/permissions/

BMJ Case Report Fellows may re-use this article for personal use and teaching without any further permission.

Become a Fellow of BMJ Case Reports today and you can:

- Submit as many cases as you like

- Enjoy fast sympathetic peer review and rapid publication of accepted articles

- Access all the published articles

Re-use any of the published material for personal use and teaching without further permission

Customer Service

If you have any further queries about your subscription, please contact our customer services team on +44 (0) 2071111105 or via email at support@bmj.com.

Visit casereports.bmj.com for more articles like this and to become a Fellow 